\title{
Low fish consumption is associated with a small increased risk of MS
}

Anna Karin Hedström, MD, PhD, Tomas Olsson, MD, PhD, Ingrid Kockum, PhD, Jan Hillert, MD, PhD, and Lars Alfredsson, PhD

Neurol Neuroimmunol Neuroinflamm 2020;7:e717. doi:10.1212/NXI.0000000000000717

\section{Abstract}

\section{Objective}

We aimed to investigate the influence of lean and fatty fish consumption on MS risk and to what extent a potential effect may be mediated by vitamin $\mathrm{D}$. We also studied the interplay between fish consumption, sun exposure, $D R B 1^{*} 15: 01$, and $A^{*} 02: 01$.

\section{Methods}

We used 2 population-based case-control studies (6,914 cases and 6,590 controls). Subjects with different fish consumption habits were compared regarding MS risk by calculating ORs with 95\% CIs using logistic regression models. The mediation effect of vitamin D on the relationship between fish consumption and MS risk was assessed. Potential interactions between fish consumption, sun exposure, and MS-associated HLA genes were assessed on the additive scale.

\section{Results}

Irrespective of sun exposure habits, low fish consumption, including both lean and fatty fish, was associated with increased MS risk (OR 1.2, 95\% CI 1.1-1.4) and interacted with the $D R B 1^{*} 15$ : 01 allele (AP 0.3, $p<0.0001$ ). The mediation analysis did not support vitamin $\mathrm{D}$ as a mediator of the association between fish consumption and MS risk. There was no interaction between fish consumption and sun exposure habits with regard to MS risk.

\section{Conclusions}

Low fish consumption and low sun exposure seem to be separate risk factors for MS. Our findings suggest that fish consumption predominantly influences MS risk by other means than by effecting vitamin $\mathrm{D}$ status, which is of relevance for prevention, in particular for those with a genetic susceptibility to MS.

\author{
Correspondence \\ Dr. Hedström \\ anna.hedstrom@ki.se
}




\section{Glossary}

BMI = body mass index; EIMS = Epidemiological Investigation of Multiple Sclerosis; GEMS = Genes and Environment in Multiple Sclerosis.

MS is an immune-mediated inflammatory disorder of the CNS. Both genetic and environmental factors and their interactions influence susceptibility to the disease. The primary genetic risk factor for MS is the $D R B 1^{*} 15: 01$ allele of the HLA-DRB1 gene, which increases the risk of disease approximately 3 -fold, but a large number of other HLAassociated alleles, such as $A^{*} 02: 01$, also affect disease risk. ${ }^{1,2}$ There are reports suggesting an association between fish consumption and $\mathrm{MS}^{3-6}$ which is also the case for sun exposure and vitamin D. ${ }^{7}$ However, it is unclear to what extent sun exposure and fish consumption associate with reduced MS risk by being sources of vitamin $\mathrm{D}$.

Recently, we demonstrated an interaction between the presence of $D R B 1^{*} 15: 01$ and both low sun exposure and vitamin D deficiency, with regard to MS risk. ${ }^{8}$ However, no previous studies have investigated the influence of fish consumption in different genetic contexts.

Using 2 population-based case-control studies, we aimed to investigate the influence of lean and fatty fish consumption on MS risk and to what extent a potential effect may be mediated by vitamin $\mathrm{D}$. We also studied the potential interplay between fish consumption, sun exposure habits, vitamin D status, DRB1 $1^{*} 15: 01$, and $A^{*} 02: 01$ status.

\section{Methods}

\section{Study design and study participants}

We used the Epidemiological Investigation of Multiple Sclerosis (EIMS) and Genes and Environment in Multiple Sclerosis (GEMS), which are Swedish population-based case-control studies on genetic and environmental factors for MS. The study population is the Swedish population aged 16-70 years. During the EIMS study period, April 2005-June 2015, incident cases of MS were recruited via 42 neurology units in Swedish hospitals, including all university hospitals. Cases were diagnosed by a neurologist according to the McDonald criteria. ${ }^{9}$ With regard to selection of controls, we have a link with direct access to the Swedish Tax Agency. For each included case in EIMS, we request 2 controls matched by age in 5-year intervals, sex, and residential area. The controls are randomly selected among those eligible by software designed for random selection at the Tax Agency. During the GEMS study period, November 2009-November 2011, all cases registered in the Swedish MS registry ${ }^{10}$ who fulfilled the McDonald criteria ${ }^{9}$ were asked to participate in GEMS if they were not included in EIMS. One control for each case was randomly selected from the national population register, matched by age in 5-year intervals, sex, and residential area where the case received its diagnosis. Controls were selected for all cases at the same time, using the same procedure as in EIMS.

\section{Standard protocol approvals, registrations, and patient consents}

Both studies were approved by the Regional Ethical Review Board at Karolinska Institutet, and all participants gave their informed consent to participate.

\section{Data collection}

In both studies, information regarding environmental exposures and lifestyle factors was collected using a standardized questionnaire. The EIMS and GEMS questionnaires were similar but not identical. Completed EIMS questionnaires were obtained from 2,880 cases and 6,122 controls, with a response rate of $93 \%$ for cases and $73 \%$ for controls. Completed GEMS questionnaires were obtained from 6,156 cases and 5,408 controls, with a response rate of $82 \%$ for cases and $66 \%$ for controls. Those who could not specify their sun exposure habits or fish consumption habits were excluded (79 cases and 95 controls in EIMS and 458 cases and 245 controls in GEMS). HLA status was available for 2,053 EIMS cases and 2,878 EIMS controls and for 4,861 GEMS cases and 3,712 GEMS controls, and these were included in the present study.

\section{Self-reported exposure information}

In EIMS, participants were asked how often, on average, they have consumed lean and fatty fish during the last 5 years. In GEMS, participants were asked how often, on average, they consumed lean and fatty fish at age 20 years. Fatty fish species were defined as species with a fat content of more than $3 \%$, such as herring, mackerel, tuna fish, salmon, and trout, whereas lean fish species were defined as species with a fat content of less than $3 \%$, such as cod, pollock, haddock, whiting, and pike perch. Each answer alternative was reported on a 4-point scale, with the answer alternatives never/seldom, 1-3 times/months, weekly, or daily. Very few participants reported daily consumption of fish, and the last 2 answer alternatives were therefore merged into one. We constructed an index by adding the numbers together and thus acquired a value between 2 (the lowest exposure) and 6 (the highest exposure). The fish consumption index is illustrated in table 1. Low fish consumption was defined as having a value below the median among controls $(<4)$, whereas more frequent consumption was defined as high fish consumption. In EIMS, information on sun exposure habits during the last 5 years was collected by asking 3 questions regarding ultraviolet radiation exposure. ${ }^{5}$ Each answer alternative was reported on a 4-point scale, and by adding the numbers together, we constructed an index ranging between 3 (the lowest exposure) and 12 (the highest exposure). 
Table 1 Fish consumption habits among cases and controls

\begin{tabular}{|c|c|c|c|c|c|c|c|c|c|}
\hline & \multicolumn{3}{|c|}{ Never or seldom fatty fish; 1 point } & \multicolumn{3}{|c|}{ Fatty fish 1-3 times/months; 2 points } & \multicolumn{3}{|c|}{ Fatty fish weekly; 3 points } \\
\hline \multicolumn{10}{|c|}{ EIMS: fish consumption habits during the 5-y period before study inclusion } \\
\hline $\begin{array}{l}\text { Never or seldom lean } \\
\text { fish; } 1 \text { point }\end{array}$ & Index $=2$ & $\begin{array}{l}\text { Cases, n (\%) } \\
\text { Controls, n (\%) }\end{array}$ & $\begin{array}{l}253(12) \\
334(12)\end{array}$ & Index $=3$ & $\begin{array}{l}\text { Cases, n (\%) } \\
\text { Controls, n (\%) }\end{array}$ & $\begin{array}{l}304(15) \\
359(12)\end{array}$ & Index $=4$ & $\begin{array}{l}\text { Cases, n (\%) } \\
\text { Controls, n (\%) }\end{array}$ & $\begin{array}{l}68(3) \\
85(3)\end{array}$ \\
\hline $\begin{array}{l}\text { Lean fish } 1-3 \text { times/ } \\
\text { months; } 2 \text { points }\end{array}$ & Index = 3 & $\begin{array}{l}\text { Cases, n (\%) } \\
\text { Controls, n (\%) }\end{array}$ & $\begin{array}{l}151(7) \\
161(6)\end{array}$ & Index $=4$ & $\begin{array}{l}\text { Cases, n (\%) } \\
\text { Controls, n (\%) }\end{array}$ & $\begin{array}{l}775(38) \\
1,096(38)\end{array}$ & Index $=5$ & $\begin{array}{l}\text { Cases, n (\%) } \\
\text { Controls, n (\%) }\end{array}$ & $\begin{array}{l}190(9) \\
320(11)\end{array}$ \\
\hline $\begin{array}{l}\text { Lean fish weekly; } \\
3 \text { points }\end{array}$ & Index $=4$ & $\begin{array}{l}\text { Cases, } \mathrm{n}(\%) \\
\text { Controls, n (\%) }\end{array}$ & $\begin{array}{l}27(1) \\
38(1)\end{array}$ & Index $=5$ & $\begin{array}{l}\text { Cases, } \mathrm{n}(\%) \\
\text { Controls, n (\%) }\end{array}$ & $\begin{array}{l}133(6) \\
207(7)\end{array}$ & Index $=6$ & $\begin{array}{l}\text { Cases, n (\%) } \\
\text { Controls, n (\%) }\end{array}$ & $\begin{array}{l}152(7) \\
280(10)\end{array}$ \\
\hline \multicolumn{10}{|c|}{ GEMS: fish consumption habits at age $20 \mathrm{y}$} \\
\hline $\begin{array}{l}\text { Never or seldom } \\
\text { lean fish; } 1 \text { point }\end{array}$ & Index = 2 & $\begin{array}{l}\text { Cases, n (\%) } \\
\text { Controls, n (\%) }\end{array}$ & $\begin{array}{l}462(10) \\
307(8)\end{array}$ & Index $=3$ & $\begin{array}{l}\text { Cases, n (\%) } \\
\text { Controls, n (\%) }\end{array}$ & $\begin{array}{l}281(6) \\
170(5)\end{array}$ & Index $=4$ & $\begin{array}{l}\text { Cases, n (\%) } \\
\text { Controls, n (\%) }\end{array}$ & $\begin{array}{l}37(1) \\
34(1)\end{array}$ \\
\hline $\begin{array}{l}\text { Lean fish 1-3 times/ } \\
\text { months; } 2 \text { points }\end{array}$ & Index $=3$ & $\begin{array}{l}\text { Cases, } \mathrm{n}(\%) \\
\text { Controls, } \mathrm{n}(\%)\end{array}$ & $\begin{array}{l}340(7) \\
214(6)\end{array}$ & Index $=4$ & $\begin{array}{l}\text { Cases, n (\%) } \\
\text { Controls, n (\%) }\end{array}$ & $\begin{array}{l}2,357(48) \\
1,916(52)\end{array}$ & Index $=5$ & $\begin{array}{l}\text { Cases, n (\%) } \\
\text { Controls, n (\%) }\end{array}$ & $\begin{array}{l}411(8) \\
357(10)\end{array}$ \\
\hline $\begin{array}{l}\text { Lean fish weekly; } \\
3 \text { points }\end{array}$ & Index $=4$ & $\begin{array}{l}\text { Cases, n (\%) } \\
\text { Controls, n (\%) }\end{array}$ & $\begin{array}{l}53(1) \\
33(1)\end{array}$ & Index $=5$ & $\begin{array}{l}\text { Cases, n (\%) } \\
\text { Controls, n (\%) }\end{array}$ & $\begin{array}{l}418(9) \\
331(9)\end{array}$ & Index $=6$ & $\begin{array}{l}\text { Cases, n (\%) } \\
\text { Controls, n (\%) }\end{array}$ & $\begin{array}{l}502(10) \\
741(20)\end{array}$ \\
\hline
\end{tabular}

Abbreviations: EIMS = Epidemiological Investigation of Multiple Sclerosis; GEMS = Genes and Environment in Multiple Sclerosis. Illustration of the fish consumption index. Low fish consumption was defined as having a fish consumption index of 2-3.

The same questions and the same answer alternatives regarding sun exposure were used in GEMS, but participants were instructed to estimate their sun exposure during summer and winter, respectively, in 10-year intervals. Sun exposure between age 10 and 29 years was considered when constructing a similar sun exposure index in GEMS, ranging between 6 (the lowest exposure) and 24 (the highest exposure). In both studies, low sun exposure was defined as having a value below the median among controls $(<6$ in EIMS and $<12$ in GEMS), whereas more frequent exposure was defined as high sun exposure.

\section{Genotyping and measurement of vitamin D}

HLA-DRB1 and HLA-A alleles were determined at 4-digit resolution. Genotyping was performed on the MS replication chip, ${ }^{11}$ which is based on an Illumina exome chip to which approximately 90,000 custom markers were added with extra high density in the HLA region, and HLA alleles were then imputed with HLA IMP:02. ${ }^{12}$ For EIMS participants recruited between 2005 and $2009(\mathrm{~N}=2,462)$, vitamin $\mathrm{D}$ status was measured as levels of 25-hydroxyvitamin D using a chemiluminescent immunoassay from DiaSorin (DiaSorin $A B$, Sundbyberg, Sweden) and a Liaison instrument provided by DiaSorin $A B$ with equimolar measurement of both 25-hydroxyvitamin $\mathrm{D}_{2}$ and $\mathrm{D}_{3}$. All samples were analyzed in a single batch. Vitamin D deficiency was defined as a value less than $50 \mathrm{nM} / \mathrm{L}$.

\section{Statistical analysis}

Subjects with different fish consumption habits were compared with regard to MS risk by calculating ORs with $95 \%$ CIs using unconditional logistic regression models. ${ }^{13}$ Lean and fatty fish were also analyzed separately. The trend test for a dose-response relationship regarding fish consumption and risk of MS was performed by using a continuous variable for fish consumption (the fish consumption index) in a logistic regression model. Trend tests for dose-response relationships were also performed for lean and fatty fish separately. The analysis of fish consumption and MS risk was stratified by sex.

Causal mediation analysis was performed to asses to what extent the relationship between consumption of fatty fish and MS risk was mediated by vitamin $\mathrm{D}$ status. The exposure variable was low consumption of fatty fish, the mediator was vitamin D deficiency, and the outcome MS. The causal effects were estimated on the OR scale, and the CIs were calculated using the delta method. ${ }^{14}$

Potential biologic interactions were assessed on an additive scale by calculating the attributable proportion due to interaction with $95 \%$ CI. To elucidate the relationship between fish consumption, sun exposure, and $D R B 1^{*} 15: 01$ status, the analysis of interaction between low fish consumption and carriage of $D R B 1^{*} 15: 01$ was stratified by sun exposure habits. We also assessed potential interactions between low sun exposure and $D R B 1^{*} 15: 01$, stratified by fish consumption habits, and between low sun exposure and low fish consumption, stratified by $D R B 1^{*} 15: 01$ status. Similar analyses were performed to study the relationship between fish consumption, sun exposure, and $A^{*} 02: 01$ status.

All analyses were adjusted for age, residential area, ancestry, and the following MS-associated HLA alleles that have been associated with MS risk independently of $D R B 1^{*} 15: 01$ status $^{1}$ : DRB1*03:01, DRB1*13:03, DRB1*08:01, $B^{*} 44: 02$, $B^{*} 38: 01, B^{*} 55: 01, D Q A 1^{*} 01: 01, D Q B 1^{*} 03: 02$, and homozygote 
correction for $D R B 1^{*} 15: 01, D R B 1^{*} 03: 01$, and $A^{*} 02: 01$. Ancestry was dichotomized into Nordic vs non-Nordic origin. A participant who was born in any of the Nordic countries, whose parents had not immigrated from outside the Nordic countries, was classified as Nordic. When appropriate, the analyses were also adjusted for sex, sun exposure habits, fish consumption habits, $D R B 1^{*} 15: 01$, and $A^{*} 02: 01$ status.

Adjustments were also made for a number of potential confounding variables that only had minor influence on the results. These factors were not kept in the final analyses and included educational level, intake of vitamin supplements, adolescent body mass index (BMI), a history of infectious mononucleosis, smoking, passive smoking, and alcohol consumption. Educational level was categorized into no postsecondary education, postsecondary education without a university degree, or university degree. Intake of vitamin supplements was dichotomized into regular intake of multivitamins or vitamin D supplements or not. Adolescent BMI was calculated by dividing self-reported weight in kilograms by self-reported height in meters squared and dichotomized into BMI $<25$ or BMI $\geq 25 \mathrm{~kg} / \mathrm{m}^{2}$. A history of mononucleosis was dichotomized into yes or no. Smoking and passive smoking were considered before the onset of disease among cases and during the same period among the corresponding controls. Smoking was dichotomized into current, past, or never smokers. Passive smoking was dichotomized into ever or never exposed. Alcohol consumption was categorized into low, moderate, or high consumption based on the number of drinks per week. $^{15}$

Table 2 Characteristics of cases and controls, overall and by fish consumption habits

\begin{tabular}{|c|c|c|c|c|c|c|}
\hline & \multicolumn{2}{|l|}{ Total } & \multicolumn{2}{|c|}{ Low fish consumption } & \multicolumn{2}{|c|}{ High fish consumption } \\
\hline & Cases & Controls & Cases & Controls & Cases & Controls \\
\hline \multicolumn{7}{|l|}{ EIMS } \\
\hline $\mathbf{N}$ & 2,053 & 2,878 & 708 & 854 & 1,345 & 2,024 \\
\hline Women, n (\%) & $1,487(72)$ & $2,160(75)$ & $513(72)$ & $639(75)$ & $974(72)$ & $1,521(75)$ \\
\hline Men, $\mathbf{n}(\%)$ & $566(28)$ & $718(25)$ & $195(28)$ & $215(25)$ & $371(28)$ & $503(25)$ \\
\hline Nordic, n (\%) & $1,677(82)$ & $2,284(79)$ & $552(78)$ & $658(77)$ & $1,125(84)$ & $1,626(80)$ \\
\hline Mean sun exposure index (SD) & $6.2(1.9)$ & $6.6(2.0)$ & $6.3(2.0)$ & $6.6(2.0)$ & $6.2(1.8)$ & $6.7(2.0)$ \\
\hline Adolescent BMI, kg/m² (SD) & $22.6(3.9)$ & $21.8(3.1)$ & $22.8(4.1)$ & $22.1(3.6)$ & $22.5(3.8)$ & $21.7(2.9)$ \\
\hline Infectious mononucleosis, n (\%) & $354(17)$ & $289(10)$ & $139(17)$ & $89(10)$ & $215(16)$ & $200(10)$ \\
\hline Smoking, n (\%) & $1,091(53)$ & $1,282(45)$ & $385(54)$ & $369(43)$ & $706(52)$ & $913(45)$ \\
\hline HLA-DRB1*15:01 & $1,122(55)$ & $799(28)$ & $398(56)$ & $213(25)$ & $724(54)$ & $586(29)$ \\
\hline$H L A-A * 02: 01$ & $851(41)$ & $1,558(54)$ & $293(41)$ & $434(51)$ & $558(41)$ & $1,124(56)$ \\
\hline Age at disease onset & $34.4(10.6)$ & & $32.5(10.0)$ & & $35.5(10.8)$ & \\
\hline \multicolumn{7}{|l|}{ GEMS } \\
\hline $\mathbf{N}$ & 4,861 & 3,712 & 1,083 & 691 & 3,778 & 3,021 \\
\hline Women, n (\%) & $3,535(73)$ & $2,852(77)$ & $761(70)$ & $526(76)$ & $2,774(73)$ & $2,326(77)$ \\
\hline Men, n (\%) & $1,326(27)$ & $860(23)$ & $322(30)$ & $165(24)$ & $1,004(27)$ & $695(23)$ \\
\hline Nordic, n (\%) & $4,206(87)$ & $3,229(87)$ & $878(81)$ & $579(84)$ & $3,328(88)$ & $2,650(88)$ \\
\hline Mean sun exposure index (SD) & $11.9(3.1)$ & $12.0(3.0)$ & $12.0(3.2)$ & $12.0(3.1)$ & $11.9(3.1)$ & $12.0(3.0)$ \\
\hline Adolescent BMI, kg/m² (SD) & $21.7(3.3)$ & $21.6(2.9)$ & $22.1(3.6)$ & $21.7(3.4)$ & $21.7(3.3)$ & $21.5(2.9)$ \\
\hline Infectious mononucleosis, $\mathrm{n}(\%)$ & $577(12)$ & $251(6.8)$ & $143(13)$ & $57(8.3)$ & $434(11)$ & $194(6.4)$ \\
\hline Smoking, n (\%) & $2,787(57)$ & $1,813(49)$ & $662(61)$ & $338(49)$ & $2,125(56)$ & 1,475 (49) \\
\hline HLA-DRB1*15:01 & $2,846(59)$ & $1,066(29)$ & $633(58)$ & $181(26)$ & $2,213(59)$ & 885 (29) \\
\hline$H L A-A * 02: 01$ & $2,115(44)$ & $2,066(56)$ & $478(44)$ & $394(57)$ & $1,637(43)$ & $1,672(55)$ \\
\hline Age at disease onset & $33.1(10.5)$ & & $31.8(10.3)$ & & $33.4(10.6)$ & \\
\hline
\end{tabular}

Abbreviations: $\mathrm{BMI}=$ body mass index; EIMS = Epidemiological Investigation of Multiple Sclerosis; GEMS = Genes and Environment in Multiple Sclerosis. 
We performed 2 subanalyses based on EIMS to be able to adjust the analyses for dietary habits and salt intake. Participants with disease onset during the last 5 years before study inclusion were included in the first subanalysis (2,209 cases and 4,610 controls). Based on a question regarding dietary habits 5 years ago, participants could choose between the following answer alternatives (1) normal diet/mixed diet, (2) vegetarian food, (3) vegetarian food including fish and shellfish, (4) vegan diet, (5) Mediterranean diet, (6) GI diet, and (7) other diet. Dietary habits were categorized based on the answer alternatives, using normal diet/mixed diet as the reference group. In the second subanalysis, we adjusted for salt intake. In November 2013, complementary questions were sent to all participants who had answered the standardized questionnaire during April 2005 to March 2013. The complementary questions were answered by 1,762 cases $(82 \%)$ and 2,975 controls (66\%). Among other questions, participants were asked to report their salt intake during different age periods. The questions were as follows: (1) how often do you eat at restaurants, including takeaway? (2) how often do you eat prepared meals or dishes that are bought at the supermarket, and (3) how often do you use extra salt on your food? The answer alternatives were less than 1 time/month, 1-3 times/month, 1-2 times/week, 3-6 times/week, daily, and several times/day. Each question was categorized based on the answer alternatives, using less than 1 time/month as the reference group.
All analyses were conducted using Statistical Analysis System (SAS) version 9.4.

\section{Data availability}

Anonymized data will be shared by request from any qualified investigator who wants to analyze questions that are related to the published article.

\section{Results}

In EIMS, the mean age at MS onset was 34 years. Almost all cases were recruited within 1 year after the diagnosis, and the questionnaires were completed after a median of 2.0 years following the onset of the disease. Characteristics of cases and controls, overall and by fish consumption habits during the 5year period before study inclusion, are presented in table 2 . The mean age at MS onset was 33 years in GEMS. The median duration between disease onset and study inclusion was 17 years. Characteristics of cases and controls, overall and by fish consumption habits at age 20 years, are presented in table 2 .

The fish consumption index was created to estimate the overall fish consumption (table 1). In both studies, the risk of MS was increased among subjects with low fish consumption (OR 1.2, 95\% CI 1.1-1.4) compared with those with high fish consumption. There were no significant sex differences (table

Table 3 OR with $95 \% \mathrm{Cl}$ of MS for subjects with low fish intake compared with those with high fish intake, overall and stratified by sex

\begin{tabular}{|c|c|c|c|c|c|c|}
\hline & \multirow[b]{2}{*}{ Fish intake } & \multicolumn{2}{|l|}{ Total } & \multicolumn{3}{|c|}{ HLA data available } \\
\hline & & $\mathrm{ca} / \mathrm{co}^{\mathrm{a}}$ & OR $(95 \% \mathrm{CI})^{\mathrm{b}}$ & $\mathrm{ca} / \mathrm{co}^{\mathrm{a}}$ & OR $(95 \% \mathrm{CI})^{\mathrm{b}}$ & OR $(95 \% \mathrm{CI})^{\mathrm{c}}$ \\
\hline \multicolumn{7}{|l|}{ EIMS } \\
\hline \multirow[t]{2}{*}{ Total } & High & $1,847 / 4,084$ & 1.0 (reference) & $1,345 / 2,024$ & 1.0 (reference) & 1.0 (reference) \\
\hline & Low & $953 / 1,839$ & $1.2(1.1-1.3)$ & $708 / 854$ & $1.2(1.1-1.4)$ & $1.2(1.1-1.4)$ \\
\hline \multirow[t]{2}{*}{ Women } & High & $1,327 / 2,946$ & 1.0 (reference) & $974 / 1,521$ & 1.0 (reference) & 1.0 (reference) \\
\hline & Low & $682 / 1,286$ & $1.2(1.1-1.3)$ & $513 / 639$ & $1.2(1.1-1.4)$ & $1.2(1.1-1.4)$ \\
\hline \multirow[t]{2}{*}{ Men } & High & $520 / 1,138$ & 1.0 (reference) & $371 / 503$ & 1.0 (reference) & 1.0 (reference) \\
\hline & Low & $271 / 553$ & $1.1(0.9-1.3)$ & $195 / 215$ & $1.2(1.0-1.5)$ & $1.2(1.0-1.6)$ \\
\hline \multicolumn{7}{|l|}{ GEMS } \\
\hline \multirow[t]{2}{*}{ Total } & High & $4,394 / 4,120$ & 1.0 (reference) & $3,778 / 3,021$ & 1.0 (reference) & 1.0 (reference) \\
\hline & Low & $1,304 / 1,043$ & $1.2(1.1-1.3)$ & $1,083 / 691$ & $1.2(1.1-1.4)$ & $1.2(1.1-1.4)$ \\
\hline \multirow[t]{2}{*}{ Women } & High & $3,221 / 3,082$ & 1.0 (reference) & $2,774 / 2,326$ & 1.0 (reference) & 1.0 (reference) \\
\hline & Low & $918 / 758$ & $1.2(1.1-1.3)$ & $761 / 526$ & $1.2(1.1-1.4)$ & $1.2(1.1-1.4)$ \\
\hline \multirow[t]{2}{*}{ Men } & High & $1,173 / 1,038$ & 1.0 (reference) & $1,004 / 695$ & 1.0 (reference) & 1.0 (reference) \\
\hline & Low & $386 / 285$ & $1.3(1.1-1.4)$ & $322 / 165$ & $1.3(1.1-1.6)$ & $1.3(1.0-1.6)$ \\
\hline
\end{tabular}

Abbreviations: EIMS = Epidemiological Investigation of Multiple Sclerosis; GEMS = Genes and Environment in Multiple Sclerosis.

a Number of exposed cases and controls.

${ }^{b}$ Adjusted for age, residential area, and ancestry and when appropriate for sex.

${ }^{c}$ Adjusted for age, residential area, ancestry, sun exposure habits, $D R B 1 * 15: 01, A * 02: 01, D R B 1 * 03: 01, D R B 1 * 13: 03, B * 44: 02, B * 38: 01, B * 55: 01, D Q B 1 * 03: 02$, homozygote correction for $D R B 1 * 15: 01, D R B 1 * 03: 01$, and $A * 02: 01$, and when appropriate for sex. 
3). Low consumption of both lean and fatty fish was significantly associated with increased MS risk in both studies, and there was a significant trend showing increasing MS risk with decreasing consumption of fatty fish ( $p$ for trend $<0.001$ in EIMS and 0.02 in GEMS). In EIMS, there was also a significant trend showing increasing MS risk with decreasing consumption of lean fish ( $p$ for trend 0.002).

There was a positive correlation between consumption of fatty fish and vitamin D status $(p<0.0001)$ and a borderline significant correlation between consumption of lean fish and vitamin $\mathrm{D}$ status $(p=0.05)$. Causal mediation analysis showed that the total effect of low consumption of fatty fish with regard to MS risk was 1.2 (95\% CI 1.0-1.5). The direct effect was 1.2 (95\% CI 1.0-1.5), whereas the magnitude of the indirect effect, mediated by vitamin $\mathrm{D}$ deficiency, was very small (OR 1.03, 95\% CI 1.00-1.06) but statistically significant. Similar results were obtained with lean fish as the exposure variable. Both the total and direct effect was 1.3 (95\% CI 1.0-1.6), and the indirect effect, mediated by vitamin D deficiency, was 1.01 (95\% CI 0.98-1.03). There was a synergistic effect between low fish consumption and $D R B 1^{*} 15: 01$, both among those who reported high and low sun exposure (table 4). The interaction became more pronounced with lower consumption of fish (table 5). There was no suggestion of an interaction between fish consumption and $A^{*} 02: 01$ status with regard to MS risk (table 6). No interaction was observed between sun exposure and fish consumption with regard to MS risk, irrespective of $D R B 1^{*} 15: 01$ status (table 7). In the subanalyses, results remained similar after adjustment for dietary habits and salt intake (data not shown).

\section{Discussion}

According to the results of the present study, low fish consumption is associated with an increased risk of developing MS. The mediation analysis did not support vitamin D as a mediator of the association between fish consumption and MS risk. Low fish consumption and low sun exposure seem to be separate risk factors for MS, and significant interactions occurred between each of these lifestyle factors and the $D R B 1^{*} 15: 01$ allele.

The mechanisms behind the association between the studied lifestyle factors and MS risk have yet to be elucidated. Fish

Table 4 OR with $95 \% \mathrm{Cl}$ of MS for subjects with different combinations of $D R B 1 * 15: 01$ status and fish consumption habits compared with $D R B 1 * 15: 01$-negative subjects with high fish consumption, overall and stratified by sun exposure habits

\begin{tabular}{|c|c|c|c|c|c|c|c|c|}
\hline \multirow[b]{2}{*}{ DRB1*15:01 } & \multirow{2}{*}{$\begin{array}{l}\text { Fish } \\
\text { consumption }\end{array}$} & \multicolumn{3}{|l|}{ Total } & \multicolumn{2}{|c|}{ Low sun exposure } & \multicolumn{2}{|c|}{ High sun exposure } \\
\hline & & $\mathrm{Ca} / \mathrm{co}^{\mathrm{a}}$ & OR $(95 \% \mathrm{Cl})^{\mathrm{b}}$ & OR $(95 \% \mathrm{Cl})^{\mathrm{c}}$ & $\mathrm{Ca} / \mathrm{co}^{\mathrm{a}}$ & OR $(95 \% \mathrm{Cl})^{d}$ & $\mathrm{Ca} / \mathrm{co}^{\mathrm{a}}$ & OR $(95 \% \mathrm{CI})^{\mathrm{d}}$ \\
\hline \multicolumn{9}{|l|}{ EIMS } \\
\hline- & High & $621 / 1,438$ & 1.0 (reference) & 1.0 (reference) & $241 / 436$ & 1.0 (reference) & $380 / 1,002$ & 1.0 (reference) \\
\hline- & Low & $310 / 641$ & $1.1(0.9-1.3)$ & $1.1(0.9-1.3)$ & $115 / 212$ & $0.9(0.7-1.2)$ & $195 / 429$ & $1.2(0.9-1.5)$ \\
\hline+ & High & $724 / 586$ & $2.9(2.5-3.3)$ & $3.1(2.6-3.6)$ & $250 / 160$ & $2.8(2.1-3.7)$ & $474 / 426$ & $3.2(2.7-3.9)$ \\
\hline \multirow[t]{2}{*}{+} & Low & $398 / 213$ & $4.3(3.5-5.2)$ & $4.5(2.7-5.5)$ & $146 / 67$ & $4.0(2.8-5.6)$ & $252 / 146$ & $4.9(3.8-6.3)$ \\
\hline & & & & AP $0.3(0.2-0.5)$ & & AP $0.3(0.04-0.6)$ & & AP $0.3(0.1-0.5)$ \\
\hline \multicolumn{9}{|l|}{ GEMS } \\
\hline- & High & $1,565 / 2,136$ & 1.0 (reference) & 1.0 (reference) & $818 / 1,028$ & 1.0 (reference) & $747 / 1,108$ & 1.0 (reference) \\
\hline- & Low & $450 / 510$ & $1.2(1.0-1.4)$ & $1.2(1.0-1.4)$ & $233 / 265$ & $1.1(0.9-1.4)$ & $217 / 245$ & $1.2(0.9-1.4)$ \\
\hline+ & High & $2,213 / 885$ & $3.5(3.1-3.8)$ & $3.5(3.1-3.9)$ & $1,171 / 422$ & $3.5(3.0-4.1)$ & $1,042 / 463$ & $3.5(3.1-4.1)$ \\
\hline \multirow[t]{2}{*}{+} & Low & $633 / 181$ & $4.8(4.0-5.7)$ & $4.9(4.0-5.9)$ & $334 / 90$ & $5.1(3.8-6.7)$ & $299 / 91$ & $5.0(3.9-6.6)$ \\
\hline & & & & AP $0.3(0.1-0.4)$ & & AP $0.3(0.1-0.5)$ & & AP $0.3(0.1-0.5)$ \\
\hline
\end{tabular}

Abbreviations: AP = attributable proportion due to interaction; EIMS = Epidemiological Investigation of Multiple Sclerosis; GEMS = Genes and Environment in Multiple Sclerosis.

${ }^{a}$ Number of exposed cases and controls.

b Adjusted for age, sex, residential area, and ancestry.

'Adjusted for age, sex, residential area, ancestry, sun exposure habits, $A * 02: 01, D R B 1 * 03: 01, D R B 1 * 13: 03, B * 44: 02, B * 38: 01, B * 55: 01, D Q B 1 * 03: 02$, homozygote correction for $D R B 1 * 15 * 01, D R B 1 * 03: 01$, and $A * 02: 01$.

${ }^{d}$ Adjusted for age, sex, residential area, ancestry, $A * 02: 01, D R B 1 * 03: 01, D R B 1 * 13: 03, B * 44: 02, B * 38: 01, B * 55: 01, D Q B 1 * 03: 02$, homozygote correction for $D R B 1 * 15: 01, D R B 1 * 03: 01$, and $A^{*} 02: 01$. 
Table 5 OR with $95 \% \mathrm{Cl}$ of MS for subjects with different combinations of $D R B 1 * 15: 01$ status and fish consumption habits compared with $D R B 1 * 15: 01$-negative subjects with high fish consumption

\begin{tabular}{|c|c|c|c|c|c|}
\hline DRB1*15:01 & Fish consumption index & $\mathrm{Ca} / \mathrm{co}^{\mathrm{a}}$ & OR $(95 \% \mathrm{Cl})^{\mathrm{b}}$ & OR $(95 \% \mathrm{CI})^{\mathrm{c}}$ & $\operatorname{AP}(95 \% \mathrm{Cl})$ \\
\hline- & 6 & $80 / 196$ & 1.0 (reference) & 1.0 (reference) & \\
\hline- & 5 & $148 / 372$ & $1.0(0.7-1.4)$ & $1.0(0.7-1.4)$ & \\
\hline+ & 6 & $72 / 84$ & $2.1(1.4-3.2)$ & $2.0(1.3-3.1)$ & \\
\hline+ & 5 & $175 / 153$ & $2.8(2.0-3.9)$ & $3.1(2.1-4.5)$ & $0.4(0.1-0.6)$ \\
\hline- & 6 & $80 / 196$ & 1.0 (reference) & 1.0 (reference) & \\
\hline- & 4 & $393 / 870$ & $1.1(0.8-1.5)$ & $1.1(0.8-1.5)$ & \\
\hline+ & 6 & $72 / 84$ & $2.1(1.4-3.2)$ & $2.0(1.3-3.1)$ & \\
\hline+ & 4 & $477 / 349$ & $3.3(2.5-4.4)$ & $3.6(2.6-4.9)$ & $0.4(0.2-0.6)$ \\
\hline- & 6 & $80 / 196$ & 1.0 (reference) & 1.0 (reference) & \\
\hline- & $2-3$ & $310 / 641$ & $1.2(0.9-1.6)$ & $1.1(0.8-1.5)$ & \\
\hline+ & 6 & $72 / 84$ & $2.1(1.4-3.2)$ & $1.9(1.2-3.0)$ & \\
\hline+ & $2-3$ & $398 / 213$ & $4.6(3.5-6.3)$ & $4.8(3.4-6.9)$ & $0.6(0.4-0.7)$ \\
\hline
\end{tabular}

Abbreviation: AP = attributable proportion due to interaction.

a Number of exposed cases and controls.

${ }^{\mathrm{b}}$ Adjusted for age, sex, residential area, and ancestry.

'Adjusted for age, sex, residential area, ancestry, sun exposure habits, $A * 02: 01, D R B 1 * 03: 01, D R B 1 * 13: 03, B * 44: 02, B * 38: 01, B * 55: 01, D Q B 1 * 03: 02$, homozygote correction for $D R B 1 * 15: 01, D R B 1 * 03: 01$, and $A * 02: 01$. The analysis is based on EIMS.

AP with $95 \% \mathrm{Cl}$ between $D R B 1 * 15: 01$ and low fish consumption.

consumption and sun exposure are important sources of vitamin $\mathrm{D}$, which has repeatedly been associated with reduced MS risk. ${ }^{16,17}$ However, the mediation analysis did not support vitamin $\mathrm{D}$ as a mediator of the association between fish consumption and MS risk. Low consumption of lean fish showed a similar impact on MS risk as did low consumption of fatty fish. Furthermore, if the influence of low sun exposure and low fish consumption both had been mediated by low levels of vitamin $\mathrm{D}$, we would have expected less impact of fish consumption on MS risk among those with high sun exposure, which was not the case.

Our findings suggest that high consumption of both lean and fatty fish may potentially protect against the development of MS. The mechanism behind the protective effect may involve any nutrient found in both types of fish. This view is strengthened by the finding that there was less than an additive effect among those who consumed high amounts of both lean and fatty fish. Lean fish is a poor source of vitamin $\mathrm{D}$ compared with fatty fish, and a potential protective effect of lean fish on MS risk has been less studied. Omega-3 fatty acids, almost exclusively found in aquatic organisms, are capable of attenuating several aspects of inflammation and have been inversely associated with both MS risk ${ }^{18,19}$ and MS progression. ${ }^{20}$ Generally, fatty fish contains more omega-3 fatty acids than lean fish, but all fish and shellfish contain some omega-3 fatty acids. Fish also contains taurine, a semiessential amino acid with anti-inflammatory and neuroprotective effects. ${ }^{21}$ Taurine analogs have been considered as potential therapeutic agents for neurologic disorders. ${ }^{21}$ Diet also has a profound influence on the gut microbiota hypothesized to affect the composition of fatty acids, which, in turn, may affect immune functions such as $\mathrm{T}$ regulatory cells. ${ }^{22,23}$

In our previous report on fish consumption and MS risk, ${ }^{6}$ based on EIMS, we found inverse associations of both lean and fatty fish in relation to risk of MS, but the association between lean fish and MS risk was not statistically significant, probably because of insufficient statistical power.

Our studies, which were designed as case-control studies, retrospectively gathered self-reported information regarding exposures and lifestyle factors. We took great care to obtain information in an identical way for cases and controls. Moreover, the questionnaires contained a wide range of questions regarding many potential environmental factors, and no section in the questionnaire was given prime focus. The risk of recall bias is greater in GEMS in which prevalent MS cases were asked to recall their fish consumption habits at age 20 years. In EIMS, incident cases of MS were asked to provide information regarding their fish consumption habits during the past 5 years. In this study, we primarily included cases of MS who had received their diagnosis within the past year to minimize recall bias. However, our observation of an association between low fish consumption and MS risk was similar in GEMS and EIMS and also in agreement with previous studies. 
Table 6 OR with $95 \% \mathrm{Cl}$ of MS for subjects with different combinations of $A^{*} 02: 01$ status and fish consumption habits compared with $A * 02: 01$-positive subjects with high fish consumption, overall and stratified by sun exposure habits

\begin{tabular}{|c|c|c|c|c|c|c|c|c|}
\hline \multirow[b]{2}{*}{$A * 02: 01$} & \multirow{2}{*}{$\begin{array}{l}\text { Fish } \\
\text { consumption }\end{array}$} & \multicolumn{3}{|l|}{ Total } & \multicolumn{2}{|c|}{ Low sun exposure } & \multicolumn{2}{|c|}{ High sun exposure } \\
\hline & & $\mathrm{Ca} / \mathrm{Co}^{\mathrm{a}}$ & OR $(95 \% \mathrm{CI})^{\mathrm{b}}$ & OR $(95 \% \mathrm{Cl})^{\mathrm{c}}$ & $\mathrm{ca} / \mathrm{co}^{\mathrm{a}}$ & OR $(95 \% \mathrm{Cl})^{\mathrm{d}}$ & $\mathrm{ca} / \mathrm{co}^{\mathrm{a}}$ & OR $(95 \% \mathrm{Cl})^{\mathrm{d}}$ \\
\hline \multicolumn{9}{|l|}{ EIMS } \\
\hline+ & High & $558 / 1,124$ & $\begin{array}{l}1.0 \\
\text { (reference) }\end{array}$ & 1.0 (reference) & $204 / 328$ & 1.0 (reference) & $354 / 796$ & 1.0 (reference) \\
\hline+ & Low & $293 / 434$ & $1.3(1.1-1.6)$ & $1.3(1.1-1.6)$ & $107 / 136$ & $1.2(0.9-1.7)$ & $186 / 298$ & $1.4(1.1-1.8)$ \\
\hline- & High & $787 / 900$ & $1.8(1.5-2.0)$ & $1.7(1.5-2.0)$ & $287 / 268$ & $1.6(1.3-2.1)$ & $500 / 632$ & $1.8(1.5-2.1)$ \\
\hline \multirow[t]{2}{*}{-} & Low & $415 / 420$ & $2.0(1.7-2.3)$ & $1.9(1.6-2.3)$ & $154 / 143$ & $1.7(1.2-2.3)$ & $261 / 277$ & $2.1(1.7-2.6)$ \\
\hline & & & & $\begin{array}{l}\text { AP }-0.07(-0.3 \text { to } \\
0.1)\end{array}$ & & $\begin{array}{l}\text { AP }-0.1(-0.5 \text { to } \\
0.3)\end{array}$ & & $\begin{array}{l}\text { AP }-0.04(-0.3 \text { to } \\
0.2)\end{array}$ \\
\hline
\end{tabular}

\section{GEMS}

\begin{tabular}{|c|c|c|c|c|c|c|c|c|}
\hline+ & High & $\begin{array}{l}1,637 / \\
1,672\end{array}$ & $\begin{array}{l}1.0 \\
\text { (reference) }\end{array}$ & 1.0 (reference) & $866 / 784$ & 1.0 (reference) & $771 / 888$ & 1.0 (reference) \\
\hline+ & Low & $478 / 394$ & $1.2(1.1-1.4)$ & $1.3(1.1-1.5)$ & $239 / 212$ & $1.1(0.9-1.3)$ & 239/182 & $1.6(1.3-2.0)$ \\
\hline- & High & $\begin{array}{l}2,141 / \\
1,349\end{array}$ & $1.6(1.5-1.8)$ & $1.6(1.4-1.8)$ & $\begin{array}{l}1,123 / \\
666\end{array}$ & $1.5(1.3-1.8)$ & $\begin{array}{l}1,018 / \\
683\end{array}$ & $1.7(1.4-1.9)$ \\
\hline \multirow[t]{2}{*}{-} & Low & $605 / 297$ & $2.1(1.8-2.4)$ & $2.0(1.6-2.3)$ & $328 / 143$ & $2.0(1.6-2.6)$ & $277 / 154$ & $1.8(1.5-2.4)$ \\
\hline & & & & $0.03(-0.2$ to 0.2$)$ & & $0.2(-0.01$ to 0.4$)$ & & $-0.2(-0.5$ to 0.1$)$ \\
\hline
\end{tabular}

Abbreviations: AP = attributable proportion due to interaction; EIMS = Epidemiological Investigation of Multiple Sclerosis; GEMS = Genes and Environment in Multiple Sclerosis.

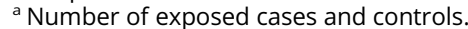

b Adjusted for age, sex, residential area, and ancestry.

${ }^{c}$ Adjusted for age, sex, residential area, ancestry, sun exposure habits, $D R B 1 * 15: 01, D R B 1 * 03: 01, D R B 1 * 13: 03, B * 44: 02, B * 38: 01, B * 55: 01, D Q B 1 * 03: 02$, homozygote correction for $D R B 1 * 15: 01, D R B 1 * 03: 01$, and $A * 02: 01$.

${ }^{d}$ Adjusted for age, sex, residential area, ancestry, $D R B 1 * 15: 01, D R B 1 * 03: 01, D R B 1 * 13: 03, B * 44: 02, B * 38: 01, B * 55: 01, D Q B 1 * 03: 02$, homozygote correction for $D R B 1 * 15: 01, D R B 1 * 03: 01$, and $A^{*} 02: 01$.

The recruitment of cases and controls may introduce selection bias. Some cases may have been unidentified in our studies. However, the Swedish health care system provides free-of-charge access to all Swedish residents, and almost all cases of MS are referred to hospital-based neurologic units. In total, 42 study centers reported cases of MS to EIMS, including all university hospitals. It is unlikely that the relatively few unidentified cases at participating centers would cause a substantial bias. A potential selection bias may result from the relatively high proportion of nonresponders among the controls. However, this bias is most likely to be modest because the prevalence of lifestyle factors, such as smoking, alcohol intake, and body mass index, among the controls was in line with that of the general population. ${ }^{24}$ There were no significant differences with respect to age, sex, or fish consumption habits between those who provided a blood sample and those who did not, indicating that selection bias did not take place in this step. The observed interactions between DRB1*15:01 and both low sun exposure and low fish consumption also alleviate some potential biases in the interpretation of the influence from the lifestyle factors on MS risk because the HLA alleles are not likely to determine exposure habits. We thus consider it unlikely that our findings would be affected by bias to a large extent, especially because such a bias would then depend on HLA types. In the present study, we had the opportunity to take a large number of potential confounding factors into account, including education, smoking, alcohol, vitamin supplements, adolescent obesity, and genetics. The factors considered only had minor influence on the results. However, the observed associations were weak or modest, and we cannot completely rule out residual confounding.

In conclusion, low fish consumption and low sun exposure seem to be separate risk factors for MS, and significant interactions take place between each of these lifestyle factors and the $D R B 1^{*} 15: 01$ allele. Our findings suggest that fish consumption predominantly influences MS risk by other means than by effecting vitamin $\mathrm{D}$ status, which is of relevance for prevention, in particular for those with a genetic susceptibility to MS.

\section{Study funding}

The study was supported by grants from the Swedish Medical Research Council, the Swedish Research Council for Health, 
Table 7 OR with $95 \% \mathrm{Cl}$ of MS for subjects with different combinations of sun exposure and fish consumption habits compared with those with high sun exposure and high fish consumption, overall and stratified by $D R B 1 * 15: 01$ status

\begin{tabular}{|c|c|c|c|c|c|c|c|c|}
\hline \multirow{2}{*}{$\begin{array}{l}\text { Sun } \\
\text { exposure }\end{array}$} & \multirow{2}{*}{$\begin{array}{l}\text { Fish } \\
\text { consumption }\end{array}$} & \multicolumn{3}{|l|}{ Total } & \multicolumn{2}{|c|}{ DRB1*15:01 positive } & \multicolumn{2}{|c|}{ DRB1*15:01 negative } \\
\hline & & $\mathrm{ca} / \mathrm{co}^{\mathrm{a}}$ & OR $(95 \% \mathrm{CI})^{\mathrm{b}}$ & OR $(95 \% \mathrm{CI})^{\mathrm{c}}$ & $\mathrm{ca} / \mathrm{co}^{\mathrm{a}}$ & OR $(95 \% \mathrm{Cl})^{\mathrm{d}}$ & $\mathrm{ca} / \mathrm{co}^{\mathrm{a}}$ & OR $(95 \% \mathrm{Cl})^{d}$ \\
\hline \multicolumn{9}{|l|}{ EIMS } \\
\hline High & High & $854 / 1,428$ & $\begin{array}{l}1.0 \\
\text { (reference) }\end{array}$ & 1.0 (reference) & $474 / 426$ & 1.0 (reference) & $\begin{array}{l}380 / \\
1,002\end{array}$ & 1.0 (reference) \\
\hline High & Low & $447 / 575$ & $1.3(1.1-1.5)$ & $1.3(1.1-1.5)$ & $252 / 146$ & $1.5(1.2-1.9)$ & $195 / 429$ & $1.2(0.9-1.5)$ \\
\hline Low & High & $491 / 596$ & $1.5(1.2-1.6)$ & $1.5(1.3-1.7)$ & $250 / 160$ & $1.5(1.1-1.9)$ & $241 / 436$ & $1.5(1.2-1.8)$ \\
\hline \multirow[t]{2}{*}{ Low } & Low & $261 / 279$ & $1.6(1.3-1.9)$ & $1.6(1.3-1.9)$ & $146 / 67$ & $2.0(1.4-2.7)$ & $115 / 212$ & $1.4(1.0-1.7)$ \\
\hline & & & & $\begin{array}{l}-0.1(-0.4 \text { to } \\
0.1)\end{array}$ & & $\begin{array}{l}0.005(-0.4 \text { to } \\
0.4)\end{array}$ & & $\begin{array}{l}-0.1(-0.5 \text { to } \\
0.2)\end{array}$ \\
\hline \multicolumn{9}{|l|}{ GEMS } \\
\hline High & High & $\begin{array}{l}1,789 / \\
1,571\end{array}$ & $\begin{array}{l}1.0 \\
\text { (reference) }\end{array}$ & 1.0 (reference) & $\begin{array}{l}1,042 / \\
463\end{array}$ & 1.0 (reference) & $\begin{array}{l}747 / \\
1,108\end{array}$ & 1.0 (reference) \\
\hline High & Low & $516 / 336$ & $1.4(1.2-1.6)$ & $1.3(1.1-1.6)$ & $299 / 91$ & $1.4(1.1-1.9)$ & $217 / 245$ & $1.3(1.0-1.6)$ \\
\hline Low & High & $\begin{array}{l}1,989 / \\
1,450\end{array}$ & $1.2(1.1-1.3)$ & $1.2(1.1-1.3)$ & $\begin{array}{l}1,171 / \\
422\end{array}$ & $1.3(1.1-1.5)$ & $\begin{array}{l}818 / \\
1,028\end{array}$ & $1.2(1.0-1.3)$ \\
\hline \multirow[t]{2}{*}{ Low } & Low & $567 / 355$ & $1.4(1.2-1.6)$ & $1.4(1.2-1.6)$ & $334 / 90$ & $1.7(1.3-2.2)$ & $233 / 265$ & $1.3(1.0-1.5)$ \\
\hline & & & & $\begin{array}{l}-0.1(-0.3 \text { to } \\
0.1)\end{array}$ & & $\begin{array}{l}0.005(-0.3 \text { to } \\
0.4)\end{array}$ & & $\begin{array}{l}-0.1(-0.4 \text { to } \\
0.2)\end{array}$ \\
\hline
\end{tabular}

Abbreviations: AP = attributable proportion due to interaction; EIMS = Epidemiological Investigation of Multiple Sclerosis; GEMS = Genes and Environment in Multiple Sclerosis.

AP with $95 \% \mathrm{Cl}$ between low sun exposure and low fish consumption.

${ }^{a}$ Number of exposed cases and controls.

${ }^{\mathrm{b}}$ Adjusted for age, sex, residential area, and ancestry.

'Adjusted for age, sex, residential area, ancestry, $D R B 1 * 15: 01, A * 02: 01, D R B 1 * 03: 01, D R B 1 * 13: 03, B * 44: 02, B * 38: 01, B * 55: 01, D Q B 1 * 03: 02$, homozygote correction for $D R B 1 * 15: 01, D R B 1 * 03: 01$, and $A * 02: 01$.

${ }^{d}$ Adjusted for age, sex, residential area, ancestry, $A * 02: 01, D R B 1 * 03: 01, D R B 1 * 13: 03, B * 44: 02, B * 38: 01, B * 55: 01, D Q B 1 * 03: 02$, homozygote correction for $D R B 1 * 15: 01, D R B 1 * 03: 01$, and $A * 02: 01$.

Working Life and Welfare, the Swedish Brain Foundation, and the Swedish Society for Medical Research.

\section{Disclosure}

A.K. Hedström reports no disclosures relevant to the manuscript. T. Olsson reports grants from the Swedish Research Council, the Knut and Alice Wallenberg Foundation, and the Swedish Brain Foundation, during the conduct of the study; grants and personal fees from Biogen, Genzyme, and Novartis; and personal fees from Merck, outside the submitted work. I. Kockum reports no disclosures relevant to the manuscript. J. Hillert received honoraria for serving on advisory boards of Biogen and Novartis and speaker's fees from Biogen, Merck Serono, Bayer Schering, Teva, and Sanofi-Aventis. He has served as principal investigator for projects sponsored by or received unrestricted research support from Biogen, Merck Serono, Teva, Novartis, and Bayer Schering. L. Alfredsson reports grants from the Swedish Research Council, the Swedish Research Council for Health Working Life and Welfare, and the Swedish Brain Foundation. Go to Neurology.org/NN for full disclosures.

\section{Publication history}

Received by Neurology: Neuroimmunology \& Neuroinflammation December 12, 2019. Accepted in final form February 25, 2020.

Appendix Authors

\begin{tabular}{lll}
\hline Name & Location & Contribution \\
\hline $\begin{array}{l}\text { Anna Karin } \\
\text { Hedström, } \\
\text { MD, PhD }\end{array}$ & $\begin{array}{l}\text { Karolinska } \\
\text { Institutet, } \\
\text { Stockholm, } \\
\text { Sweden }\end{array}$ & $\begin{array}{l}\text { Designed and conceptualized the } \\
\text { study; analyzed the data; and } \\
\text { drafted the manuscript }\end{array}$ \\
\hline $\begin{array}{l}\text { Tomas } \\
\text { Olsson, MD, } \\
\text { PhD }\end{array}$ & $\begin{array}{l}\text { Karolinska } \\
\text { Institutet, } \\
\text { Stockholm, } \\
\text { Sweden }\end{array}$ & $\begin{array}{l}\text { Designed and conceptualized the } \\
\text { study; interpreted the data; and } \\
\text { revised the manuscript }\end{array}$ \\
\hline $\begin{array}{l}\text { Ingrid } \\
\text { Kockum, PhD }\end{array}$ & $\begin{array}{l}\text { Karolinska } \\
\text { Institutet, } \\
\text { Stockholm, } \\
\text { Sweden }\end{array}$ & $\begin{array}{l}\text { Interpreted the data and revised } \\
\text { the manuscript }\end{array}$ \\
\hline Jan Hillert, \\
MD, PhD & $\begin{array}{l}\text { Karolinska } \\
\text { Institutet, } \\
\text { Stockholm, } \\
\text { Sweden }\end{array}$ & $\begin{array}{l}\text { Designed and conceptualized the } \\
\text { study; interpreted the data; and } \\
\text { revised the manuscript }\end{array}$ \\
\end{tabular}


Appendix (continued)

\begin{tabular}{|c|c|c|}
\hline Name & Location & Contribution \\
\hline $\begin{array}{l}\text { Lars } \\
\text { Alfredsson, } \\
\text { PhD }\end{array}$ & $\begin{array}{l}\text { Karolinska } \\
\text { Institutet, } \\
\text { Stockholm, } \\
\text { Sweden }\end{array}$ & $\begin{array}{l}\text { Designed and conceptualized the } \\
\text { study; interpreted the data; and } \\
\text { revised the manuscript }\end{array}$ \\
\hline
\end{tabular}

\section{References}

1. Moutsianas L, Jostins L, Beecham AH, et al. Class II HLA interactions modulate genetic risk for multiple sclerosis. Nat Genet 2015;47:1107-1113.

2. Lincoln MR, Montpetit A, Cader MZ, et al. A predominant role for the HLA class II region in the association of the MHC region with multiple sclerosis. Nat Genet 2005;37:1108-1112.

3. Ghadirian P, Jain M, Ducic S, et al. Nutritional factors in the aetiology of multiple sclerosis: a case-control study in Montreal, Canada. Int J Epidemiol 1998;27:845-852.

4. Kampman MT, Wilsgaard T, Mellgren SI. Outdoor activities and diet in childhood and adolescent relate to MS risk above the Arctic Circle. J Neurol 2007;254:471-477.

5. Bäärnhielm M, Olsson $\mathrm{T}$, Alfredsson L. Fatty fish intake is associated with decreased occurrence of multiple sclerosis. 2014;20:726-732.

6. Abdollahpour I, Nedjat S, Mansournia MA, et al. Estimating the marginal causal effect of fish consumption during adolescence on multiple sclerosis: a population-based incident case-control study. Neuroepidemiology 2018;50:111-118.

7. Lucas RM, Byrne SN, Correale J, et al. Ultraviolet radiation, vitamin D and multiple sclerosis. Neurodegener Dis Manag 2015;5:413-424.

8. Hedström AK, Olsson T, Kockum I. Hillert J, Alfredsson A. Low sun exposure increase multiple sclerosis risk both directly and indirectly. J Neurol Epub 2019 Dec 17.

9. Thoompson AJj, Montalban X, Barkhof F, et al. Diagnostic criteria for primary progressive multiple sclerosis: a position paper. Ann Neurol 2000;47:831-835.

10. Hillert J, Stawiarz L. The Swedish MS registry - clinical support tool and scientific resource. Acta Neurol Scand 2015;132:11-19.
11. International Multiple Sclerosis Genetics Consortium. Multiple sclerosis genomic map implicates peripheral immune cells and microglia in susceptibility. Science 2019; 365:eaav7188

12. Dilthey A, Leslie S, Moutsianas L, et al. Multi-population classical HLA type imputation. PLoS Comput Biol 2013;9:e1002877.

13. Pearce N. Analysis of matched case-control studies. BMJ 2016;352:1969.

14. Valeri L, Vanderweele TJ. Mediation analysis allowing for exposure-mediator interactions and causal interpretation: theoretical assumptions and implementation with SAS and SPSS macros. Psychol Methods 2013;18:137-150.

15. Hedström AK, Hillert J, Olsson T, Alfredsson L. Alcohol as a modifiable lifestyle factor affecting multiple sclerosis risk. JAMA Neurol 2014;71: 300-305.

16. Lucas RM, Byrne SN, Correale J, Ilschner S, Hart PH. Ultraviolet radiation, vitamin D and multiple sclerosis. Neurodegener Dis Manag 2015;5:413-424.

17. Sundström P, Salzer J. Vitamin D and multiple sclerosis: from epidemiology to prevention. Acta Neurol Scand 2015;132:56-61.

18. Bjornevik K, Chitnis T, Ascherio A, Munger KL. Polyunsaturated fatty acids and the risk of multiple sclerosis. Mult Scler 2017;23:1830-1838.

19. Hoare S, Lithander F, van der Mei I, Ponsonby AL, Lucas R. Higher intake of omega-3 polyunsaturated fatty acids is associated with a decreased risk of a first clinical diagnosis of central nervous system demyelination: results from the Ausimmune Study. Mult Scler J 2016;22:884-892.

20. AlAmmar WA, Albeesh FH, Ibrahim LM, et al. Effect of omega-3 fatty acids and fish oil supplementation on multiple sclerosis: a systematic review. Nutr Neurosci Epub 2019 Aug 28.

21. Jakaria M, Azam S, Haque ME, et al. Taurine and its analogs in neurological disorders: focus on therapeutic potential and molecular mechanisms. Redox Biol 2019;24 101223.

22. Hirschberg S, Gisevius B, Duscha A, Haghikia A. Implications of diet and the gut microbiome in neuroinflammatory and neurodegenerative diseases. Int J Mol Sci 2019;20:E3109.

23. Haase S, Haghikia A, Wilck N, et al. Impacts of microbiome metabolites on immune regulation and autoimmunity. Immunology 2018;154:230-238.

24. Internet-based information. Available at: http://www.statistikdatabasen.scb.se/ pxweb/sv/ssd/. Accessed November 10, 2018 


\section{Neurology \\ Neuroimmunology \& Neuroinflammation}

Low fish consumption is associated with a small increased risk of MS

Anna Karin Hedström, Tomas Olsson, Ingrid Kockum, et al.

Neurol Neuroimmunol Neuroinflamm 2020;7;

DOI 10.1212/NXI.0000000000000717

This information is current as of April 10, 2020

\section{Updated Information \& Services}

References

Citations

Subspecialty Collections

Permissions \& Licensing

Reprints including high resolution figures, can be found at:

http://nn.neurology.org/content/7/3/e717.full.html

This article cites 19 articles, 1 of which you can access for free at: http://nn.neurology.org/content/7/3/e717.full.html\#\#ref-list-1

This article has been cited by 1 HighWire-hosted articles: http://nn.neurology.org/content/7/3/e717.full.html\#\#otherarticles

This article, along with others on similar topics, appears in the following collection(s):

Multiple sclerosis

http://nn.neurology.org//cgi/collection/multiple_sclerosis

Information about reproducing this article in parts (figures,tables) or in its entirety can be found online at:

http://nn.neurology.org/misc/about.xhtml\#permissions

Information about ordering reprints can be found online: http://nn.neurology.org/misc/addir.xhtml\#reprintsus

Neurol Neuroimmunol Neuroinflamm is an official journal of the American Academy of Neurology.

Published since April 2014, it is an open-access, online-only, continuous publication journal. Copyright

Copyright $\odot 2020$ The Author(s). Published by Wolters Kluwer Health, Inc. on behalf of the American

Academy of Neurology.. All rights reserved. Online ISSN: 2332-7812.

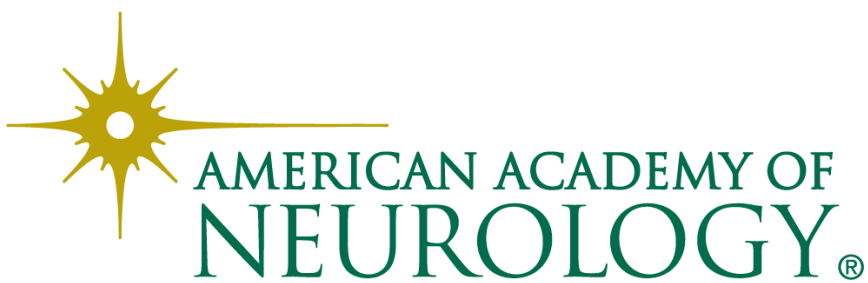

